\title{
PERSON OWNER FIT IN MICRO, SMALL AND MEDIUM COMPANIES
}

\author{
DOI: 10.17261/Pressacademia.2019.1019 \\ RJBM- V.6-ISS.1-2019(3)-p.24-34
}

\author{
P. Edi Sumantri ${ }^{1}$, Christantius Dwiatmadja $^{2}$, Ade Banani ${ }^{3}$ \\ ${ }^{1}$ Jenderal Soedirman University, Doctoral Program in Management Science Faculty of Economics and Business, Purwokerto, Indonesia. \\ mantriuwk67@yahoo.co.id, ORCID: 0000-0002-1289-9725 \\ 2 Satyawacana Christian University, Department of Economics and Business, Salatiga, Indonesia. \\ christantius.dwiatmadja@staff.uksw.edu, ORCID: 0000-0002-8849-7562 \\ 3 Jenderal Soedirman University, Department of Economics and Business, Purwokerto, Indonesia. \\ a.banani@yahoo.com ORCID: 0000-0002-9899-8598
}

Date Received: December 27, 2018

Date Accepted: March 4, 2019

To cite this document

Sumantri, P. E., Dwiatmadja, C., Banani, A. (2019). Person owner fit in micro, small and medium companies. Research Journal of Business and Management (RJBM), V.6(1), p.24-34.

Permemant link to this document: http://doi.org/10.17261/Pressacademia.2019.1019

Copyright: Published by PressAcademia and limited licenced re-use rights only.

\section{ABSTRACT}

Purpose - The main purpose of this study is to examine whether the Person Owner Fit as a dimension developed in the theory of Person Environment Fit has a significant influence on job satisfaction and intention to leave.

Methodology - In this study we tested a sample of employees working in the micro, small and medium business sector in Banyumas district, Central Java, Indonesia, as many as 225 respondents, using structural equation modelling (SEM).

Findings - The test results show p-value of $0.011<0.05$ (cut of value), with its CR value of $2.542>2.00$ and p-value of $0.102>0.05$ (cut of value), with its CR value amounting to $1,634<2,00$

Conclusion - There is a positive and significant effect of the dimension of Person Owner Fit (P_Own_Fit) on job satisfaction, and there is no significant effect of the Person Owner Fit (P_Own_Fit) dimension on the intention to leave.

Keywords: Person-owner fit, person-job fit, job satisfaction, intention to leave.

JEL Codes: K31, K41, J41

\section{INTRODUCTION}

Conformity, match, and harmony are important factors that must be considered by various parties to achieve the same goal. In organizations it can be done through consideration of various aspects that involve employee values and values that exist within the organization. The theory used in examining conformity aspects refers to person-environment (PE) fit theory (Caplan, 1983; French, 1974), who assume that individuals prefer an environment having similar characteristics to themselves (Kroeger, 1995). PE-Fit is compatibility that occurs when there is a match between the characteristics of an individual and his/her working environment (Kristof-Brown, Zimmerman, \& Johnson, 2005). In assessing conformity aspects, researchers generally try to compare the internal aspects of an individual (for example, values, personality, goals, abilities) with elements from the external environment (for example, values, culture, climate, goals, and demands) as ways to understand and predict employee attitudes and behaviour. Behaviour is considered as a function of the interaction between people and situational factors (Cable $\&$ Judge, 1996; Chatman, 1989; Schneider, 1987).

The theory of Person-Environment Fit (PE-Fit) has developed measurements of aspects of conformity, match, harmony between individuals and their environment, so that this theory is considered to be able to construct concepts used in measuring various types of "fit" or conformity, which encourage the concept to develop into a construct multidimensional fit (Kristof-Brown \& Guay, 2011). This is in accordance with the concept stated by Harrison (2007) who assesses compatibility or suitability by 
combining one or more attributes that focus on individuals and their environment (J. R. Edwards, 2008; Harrison, 2007). Multidimensional constructs of conformity at various levels that have been developed by researchers to date include: PersonVocation fit (PV Fit), Person-Job Fit (PJ Fit), Person-Organization Fit (PO Fit), Person-Team Fit atau Person-Group Fit (PG Fit), Person-Individual Fit (PI Fit).

Person-Vocation Fit refers to the suitability taking place between the work environment and the expertise and interests of individuals towards work that leads to vocational related to one's career path (Holland, 1997; Moos, 1987; Parsons, 1909; Super, 1953). Person-Job Fit (P-J Fit) is the suitability of individuals with their jobs (J. R. Edwards, 1991). At the organizational level, Person-Organization Fit is used to assess aspects of conformity between individuals and the organizations in which they work (Kristof-Brown, 1996), this suitability encourages employees to do their job according to the characteristics and values that exist within the organization. At the group level the dimensions of Person-group fit, or person-team fit are often used to consider conformity or match that focuses on individuals with their coworkers and work teams (Kristof-Brown \& Stevens, 2001; Kristof-Brown, Barrick, \& Kay Stevens, 2005; Werbel \& Gilliland, 1999). Conformity at the individual level has developed the Person-Individual Fit dimension that describes the suitability of individuals with other individuals in explaining reciprocal relationships in their work environment.

The Person-Individual Fit dimension assesses similarity, match, harmony, in various aspects such as personality whose results show that personality similarities are associated with more quality exchanges between leaders and followers (Ashkanasy \& O'connor, 1997; Bauer \& Green, 1996; Engle \& Lord, 1997; Graen \& Cashman, 1975; Liden, Wayne, \& Stilwell, 1993; Phillips \& Bedeian, 1994; Steiner \& Dobbins, 1989), thus improving better interpersonal relationships, higher performance, facilitating communication, increasing effectiveness in interaction (Engle \& Lord, 1997; Meglino, Ravlin, \& Adkins, 1991; Miles, 1964), increase the amount of communication between individuals (Engle \& Lord, 1997; Lincoln \& Miller, 1979; Miles, 1964), social integration in organizations (O'Reilly, Caldwell, \& Barnett, 1989), and reduce conflict and role ambiguity (Tsui \& O'reilly, 1989; Turban \& Jones, 1988). Perspectives that explore dimensions of conformity in the domain of Person Supervisors Fit (PS-Fit) tend to assess the compatibility between leaders and subordinates through various aspects considered such as values (Hoffman, Bynum, Piccolo, \& Sutton, 2011; Vianen, 2000), personality (Schaubroeck \& Lam, 2002), work style (Turban \& Jones, 1988), lifestyle (Dimarco, 1975), and leadership style (Chuang, Judge, \& Liaw, 2012).

The PE-Fit research is mostly applied to medium and large scale organizations whose organizational structure is well established and managed by management without direct involvement from the owner. However, PE Fit research has not been applied to smaller scale organizations such as micro, small and medium enterprises (MSMEs) which are often characterized by the owner's active involvement in managing his business. In general, small business owners want to have control over their environment (Cardon \& Stevens, 2004; Jack, Hyman, \& Osborne, 2006) and ensure that employees will share the same values and beliefs (Williamson, 1981). This illustrates the situation of MSMEs, which generally show owner dominance and are actively involved in managing their business. Communication between the owner as a leader and their employees can lead to harmonious relationships in a family atmosphere (Matlay, 1999), and flexible work practices are factors that support the success of small businesses (Walker \& Brown, 2004). Thus, the compatibility between employees and owners is an important factor that needs to be explored further to support the success of MSMEs.

The dimensions of Person-Individual Fit (PI Fit) to date have explored the relationship between individuals and their colleagues (Antonioni \& Park, 2001), job applicants with recruiters (Graves \& Powell, 1995), mentor to protege (Turban \& Dougherty, 1994), leaders with subordinates (Adkins, Russell, \& Werbel, 1994; Kristof-Brown, Zimmerman, et al., 2005; Vianen, 2000), followers and leaders (Colbert, 2004; Krishnan, 2002), similarity of superior personality with subordinates (Schaubroeck \& Lam, 2002), suitability of manager's goals with employees (Witt, 1998). However, researches related to the PE-Fit field are hardly to find. There has not been found a match between the employee and the business owner (Owner) who also acts as the leader of the company, so researchers assume this concept needs to be developed by expanding the dimensions in the Person Environment Fit theory so that this theory can be applied more flexibly to organizations in all business scales.

The Person Environment Fit theory which includes multidimensional conformity can only be used to measure conformity in large and well-established organizations, but the theory cannot be applied to organizations with micro and small scale businesses because they are still managed by the owner. Therefore, it is necessary to add a dimension of conformity that can be applied to micro and small businesses so that the theory of Person Environment Fit can be applied in all business scales, these dimensions are named as the Person Owner Fit dimension. 


\section{LITERATURE REVIEW}

\subsection{MSMEs in Indonesia}

The number of business actors in Indonesia is still dominated by MSMEs having a considerable contribution in creating jobs, acting as a place to earn income and develop skills. (Sartika \& Soedjoedono, 2002). MSMEs are called as sectors having labour intensive not capital intensive (BI, 2011), it means more empowering the workforce to obtain optimal results, so that human resource management must be applied appropriately in order to be able to grow and develop better.

In this study, the definition of MSMEs refers to the Indonesian Central Bureau of Statistics (BPS), using reference based on the quantity of labour, with the criteria for micro businesses having a workforce of $1-4$ people, small businesses having a workforce of 5 to 19 people and medium-sized businesses having workers 20 to 99 people ("Badan Pusat Statistik, Kabupaten Banyumas," 2017).

\subsection{Person Owner Fit (P Own Fit)}

This dimension was developed based on the theory of social exchange which became the root of the development of psychological contracts. Social Exchange Theory shows that rational personal interests encourage social interaction of society and personality are the main driving factors of human behaviour in the organization (House, Shane, \& Herold, 1996). This means that individuals in relationships with others will try to maximize the benefits they get (Blau, 1964; Homans, 1958). The concepts that develop in psychological contracts are grouped into transactional contracts and relational contracts. The contract emphasizes "a belief system that an individual and his/her employer will hold an exchange agreement between them" (Dabos \& Rousseau, 2004).

Transactional contracts are more directed at economic motives and short-term work agreements, while relational contracts focus more on affective involvement and personality development on the job and expect long-term employment relationships (Millward \& Brewerton, 1999). High involvement and attachment in relational psychological contracts, is characterized by the similarity of views in relationships made between employers and workers (Filotheos Ntalianis, 2015). The long-term, proactive and dedicated actions of employees will create a climate full of trust, and at the same time become a key component of psychological relationships (Montes \& Irving, 2008). Relational contracts are said to have a positive relationship with psychological ownership (Aggarwal \& Bhargava, 2010), this is associated with long-term security which creates a feeling of attachment to the organization. This feeling is characterized by the individual's perception of ownership of an object both material and immaterial that can manifest itself (Belk, 1988; Dittmar, 1992; James, 1890). Thus, the suitability between employees and owners will build psychological ownership in employees so that it is assumed that the Person Owner Fit has a negative correlation with the desires or intentions of employees leaving the organization or company.

Hypothesis 1: The Person Owner Fit has a negative and significant influence on the desires or intentions of employees leaving the organization

The Person Owner Fit dimension also refers to the ASA (Attraction, Selection, and Attrition) framework model that illustrates that organizational goals are stated implicitly or explicitly by the founder in the hope of generating policies, special practices and their combination to develop organizations with structural, process and cultural characteristics special. The ASA framework model will determine the characteristics of people who are interested, chosen by, and who remain in the organization (Schneider, Goldstiein, \& Smith, 1995). Individual interest in a particular organization is initially based on implicit estimates of the suitability of individual characteristics with the attributes inherent in potential work organizations. The next stage refers to formal and informal selection procedures used by organizations in recruiting and hiring people according to the attributes desired by the organization. The final stage emphasizes the process of friction so that people will leave organizations they don't like. Thus, the ASA framework model will form an environment that results in homogeneity because the same people will live in different organizations and will leave (Schneider et al., 1995), this leads to the existence of suitability between employees and the owner.

To differentiate between the dimensions of Person Owner Fit (P-Own-Fit) and the dimensions of Person Individual Fit (PI Fit), the basis of Stewardship theory is used to describe situations when executives as stewards / servants are motivated to act according to principals' wishes, they will not leave the organization and try reaching the target organization (Donaldson \& Davis, 1991). This theory emphasizes the existence of aspects relating to the owner, while the PI Fit dimension developed in the PE-Fit theory has not shown involvement directly from the owner of the organization or company. Conformity or matching of views between owners and employees is one aspect that needs to be developed in micro, small and medium enterprises, because business owners generally still rely on their employees not only to carry out their assigned tasks, but also ready to use their initiatives in working outside which has been narrowly defined in the job description (Gatewood \& Feild, 1987). Thus the Person 
Owner Fit (P-Own-Fit) can be seen as a dimension that needs to be considered in assessing the suitability between employees and business owners as well as supporting multidimensional developments in the Person-Environment Fit theory, and it is assumed that the Person Owner Fit has a positive correlation with satisfaction employee work.

Hypothesis 2: Person Owner Fit has a positive and significant influence on employee job satisfaction

\subsection{Person Job Fit (PJ-Fit)}

This dimension refers to the suitability of a person's characteristics with the characteristics of his work. Experts define PersonJob Fit (P-J Fit) as a match between a person's ability to the demands of his work (i.e., demands-abilities) or someone's desires with his work attributes (needs-supplies) (J. R. Edwards, 1991; Kristof-Brown, 1996). Demands-abilities (DA) include aspects related to KSA (knowledge, skills and abilities) and personality, while needs-supplies fit includes aspects related to the interests and characteristics of work (Chuang, Shen, \& Judge, 2016). Complementarity-based perspective (Muchinsky \& Monahan, 1987) in relation to DA Fit, it states that one can complete the characteristics of his environment when there is a match of one's ability to the requirements of the job with the content of DA Fit, namely "KSAO" (Knowledge, Skill, Ability, and Other characteristics) (Kristof-Brown, 2000; Rynes \& Gerhart, 1993).

Experience in work can be a determining factor in assessing P-J Fit, in addition to the possibility that requires work that must be held by individuals who have certain personality types to obtain better performance (Rynes \& Gerhart, 1993). Personality characteristics and skills / expertise related to work are considered to be important factors to assess perceptions of complementary compatibility (Piasentin \& Chapman, 2007), this is in line with research that emphasizes personality aspects in measuring perceptions of conformity with work (Lauver \& Kristof-Brown, 2001). In considering aspects of meeting needs, individuals will compare their own needs with regard to recognition and social involvement with those provided by the environment (French \& Kahn, 1962). So, the suitability of interests will support positive results such as satisfaction, retention, and achievement, in accordance with empirical evidence that shows that the P-J Fit is related to job performance / work (Li \& Hung, 2010; Wang, Zhan, McCune, \& Truxillo, 2011), job satisfaction (Cable \& DeRue, 2002; Wang et al., 2011), turnover / turnover intentions (Wang et al., 2011), turnover / turnover decisions (Cable \& DeRue, 2002), and OCB (Organizational Citizenship Behaviours) (Li \& Hung, 2010), so that hypotheses 3 and 4 are developed as follows:

Hypothesis 3: Person Job Fit has a positive and significant influence on employee job satisfaction.

Hypothesis 4: Person Job Fit has a negative and significant influence on employee's intention to leave the organization.

\subsection{Job Satisfaction}

A pleasant or positive emotional state that results from an assessment of one's work or work experience (Locke, 1976), and other opinions state that cognitive and / or affective evaluations of one's work are more or less positive or negative (Brief \& Weiss, 2002). Job satisfaction has the potential to influence various behaviours in the organization and contribute to the level of employee welfare (George; \& Jones, 2012), so that employee job satisfaction is an important indicator for the organization. Employee satisfaction or dissatisfaction has implications for employee performance, organizational commitment, organizational citizenship behaviour, intention to move or turn over, and work attitude. Job satisfaction is positively correlated with employee performance and with organizational commitment (George; \& Jones, 2012; Judge \& Larsen, 2001). Employees who are satisfied with their jobs tend to perform better than those who are not satisfied. Job dissatisfaction, on the other hand, has been linked to absenteeism, delay, turn over, and other negative attitudes (Randolph \& Johnson, 2005). Job satisfaction is also explained by various types of P-E fit (Spanjol, Tam, \& Tam, 2015; Yu, 2016)

\subsection{Intention to Leave}

Job satisfaction results in less intention to quit (Hom \& Griffeth, 1995) and often associated with a decrease in intention to leave the company (Jaramillo, J. P. Mulki., \& Solomon, 2006). Job satisfaction is also an important factor that influences the intention to leave the profession (Sabanciogullari \& Dogan, 2015). Thus it can be assumed that job satisfaction affects the intention to leave.

Hypothesis 5: Job satisfaction has a negative and significant correlation with the intention of employees to leave the organization. 


\section{DATA AND METHODOLOGY}

This research was designed by using a survey and the respondents were workers/employees working in the processing and trade sectors related to Banyumas especially in the micro, small, and medium scale business scale. The questionnaires were distributed to 356 respondents both off line and on line, and collected 247 as many questionnaires, or the number of response rates of $69.38 \%$. The amount of 225 is considered to meet the requirements for further analysis. Sampling used was purposive sampling by considering the relationship between employees working at least 1 year with the business owner who also acts as the business leader, and the location of micro, small and medium enterprises is Banyumas District, Central Java Province, Indonesia.

\subsection{Measurement}

This study was designed using closed questions, with an interval scale measurement scale in the form of bipolar. Adjective with a value range (score) of 1 to 10 , which has two extreme points namely strongly agree and strongly disagree (Agree-Disagree Scale) (Ferdinand, 2006).

The indicators used in measuring the dimensions of the Person Owner Fit refer to the compatibility between the leader and his/her subordinates such as assessing conformity or alignment relating to things that are valued by employees in their lives with things valued by business owners; employee personality with the personality of the business owner; employee work style with the work style of the business owner; the lifestyle of employees with the lifestyle of business owners; leadership style wanted by employees from their leaders with the leadership style applied by business owners in the workplace (Chuang et al., 2012; Chuang et al., 2016; Dimarco, 1975; Hoffman et al., 2011; Turban \& Jones, 1988; Vianen, 2000).

The indicator used in measuring the dimensions of Person Job Fit (PJ Fit) is measured using items developed by Edward (J. R. Edwards, 1996; Lauver \& Kristof-Brown, 2001) include: suitability of employees' abilities with job demands, suitability of employee skills to carry out work, suitability of job requirements with employee expertise, suitability of employee's personality with work, and suitability of individual employee characteristics for existing types of work.

The indicators used in measuring the dimensions of job satisfaction were carried out by taking the scale of job satisfaction versions from Braifield and Rothe (Brayfield \& Rothe, 1951) and used in job satisfaction research (Ilies \& Judge, 2002; Saari \& Judge, 2004) include: comparison of existing work with ideal work; very favoured work; work provides satisfaction; still choose the current job; size when the employee takes the first job; recommend friends to work in the workplace at this time.

The indicators used in measuring the dimensions of intention to leave include: the frequency of employees thinking of quitting work, next year they will actively seek new jobs outside of this company, and often see several job advertisements in their fields (Cammann, Fichman, Jenkins, \& Klesh, 1979; Chen, Hui, \& Sego, 1998; Valentine, Godkin, Fleischman, \& Kidwell, 2011).

\section{FINDINGS AND DISCUSSIONS}

\subsection{Research Results}

Data normality test is used to avoid bias and inefficiency of the results obtained. The results of the calculation of skewness and kurtosis obtained univariate values on the data all showed critical values between \pm 2.58 , and multivariate values obtained for 0.160 thus assuming the normality of the data is met. The results of univariate testing of data outliers obtained no Z-score value $>3$ and no Z-score value $<-3$, then univariate can not be said to contain the value of outliers. Testing of multivariate outliers by paying attention to the mahalanobis distance value with the highest value of 35.765 and the chi-square value of $132.8, \mathrm{df}=146$ from the distribution table $\chi 2$ obtained by the number 188.66 . Because the value of the mahalanobis distance $<$ chi-square can be said there are no cases that look extreme so the data can be used for further analysis. Evaluation of indications of multicollinearity and singularity is indicated by the determinant value of the sample covariance matrix which is close to zero. The results of the analysis in this study obtained a value of 1.379 which indicates that the determinant value of the sample covariance matrix is far from zero so that it can be concluded that there is no multicollinearity and singularity. Evaluation of the Goodness of Fit criteria can be seen from the results of the analysis as in the following table: 
Table 1: Model Accuracy Test

\begin{tabular}{lccc}
\hline GFI & RMR & CV & ME \\
\hline$\chi^{2}-$ Chi Square & 132,810 & $\chi^{2}$ tabel df(0,01,146)=188,6 & Good \\
Significance Probability & 0,776 & $\geq 0,05$ & Good \\
RMSEA & 0,000 & $\leq 0,08$ & Good \\
GFI & 0,944 & $\geq 0,90$ & Good \\
AGFI & 0,928 & $\geq 0,90$ & Good \\
CMIN/DF & 0,910 & $\leq 2,00$ & Good \\
TLI & 1,019 & $\geq 0,95$ & Good \\
CFI & 1,000 & $\geq 0,95$ & Good \\
\hline
\end{tabular}

Note: GFI: Goodness of Fit Index; RMR: Research Model Results; CV: Cut of Value; ME: Model Evaluation; DF: degree of freedom; RMSEA: Root Mean Square Error of Approximation; AGFI: Adjusted goodness of fit; CMIN/DF: the minimum sample discrepancy function/degree of freedom; TLI: Tucker Lewis Index; CFI: Comparative fit index

The results of the feasibility assessment model show a relatively small chi-square value $\left(\chi^{2}\right.$ table $\left.\mathrm{df}(0,01,146)=188,6\right)$, the probability value of 0,776 is well above the recommended 0.05 limit, the RMSEA value of 0,000 is smaller than the value limit that is permitted is $0.08, \mathrm{GFI}$ and AGFI are greater than the allowed value limit of 0.9 , and CMIN / DF of 0.910 is smaller than 2.0. Incremental fit index which includes Tucker Lewis index obtained TLI value of $1.019 \geq 0.95$, and comparative fit index (CFI) obtained CFI value of $1,000 \geq 0.95$, so it can be said that the model is good / good.

The direct influence of Person Owner Fit on job satisfaction is 0.306 , Person Job Fit's direct influence on job satisfaction is 0.333 . Person Owner Fit's direct influence on intention to exit is $-0,188$, Person Job Fit's direct influence on intention to exit is 0.339 . The direct effect of job satisfaction on intention to leave is 0.358 . Indirect influence of Person Owner Fit on job satisfaction of 0,000 Person Job Fit indirect influence on job satisfaction of 0,000 . Person Owner Fit's indirect influence on intention to exit is 0.109 , Person Job Fit's indirect influence on intention to exit is 0.119 . Indirect influence of job satisfaction on intention exits by 0,000 . The influence of the total Person Owner Fit on job satisfaction is 0.306 , the total influence of Person Job Fit on job satisfaction is 0.333 . The effect of the total Person Owner Fit on Intention to exit is -0.079 , the effect of the total Person Job Fit on Intention to exit is 0.458 . The total effect of job satisfaction on intention to leave is 0.358 .

Figure 1: The Effect of Person Job Fit, Person Owner Fit on Job Satisfaction and Intention to Leave

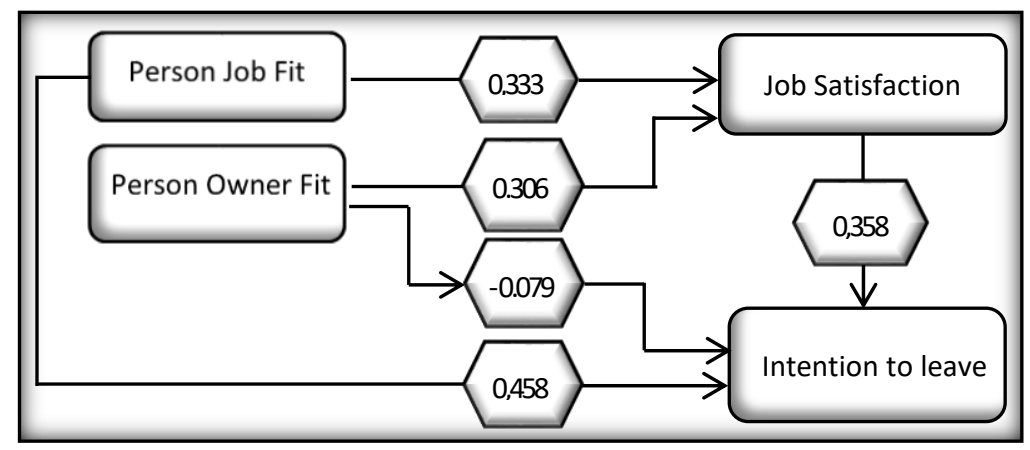

Table 2: Causality Between Variables

\begin{tabular}{clccc}
\hline No & Causal Relationships & CR & P & Conclusion \\
\hline 1. & Person Owner Fit to Intention to leave & -1.634 & 0.102 & Not Significant \\
2. & Person Owner Fit for job satisfaction & 2.542 & 0.011 & Significant \\
3. & Person Job Fit towards job satisfaction & 2.818 & 0.005 & Significant \\
4. & Person Job Fit for Intention to leave & 2.846 & 0.004 & Significant \\
5. & Job satisfaction with intention to leave & 2.815 & 0.005 & Significant \\
\hline
\end{tabular}


From the results of calculations using AMOS 18 it can be concluded that hypothesis 1 is partially accepted, meaning that the dimensions of the Person Owner Fit has a negative influence on the intention to leave the company, but it is not significant because the value of $p>0.05$. Hypotheses 2 and 3 are accepted. Hypothesis 4 is partly accepted because Person Job Fit has a significant influence on intention to leave but has a positive effect. Hypothesis 5 is partly accepted, this is because job satisfaction has a significant influence on intention to leave but has a positive effect.

\subsection{Discussion}

As mention at the objective of the research, this study examines two dimensions of conformity to see its effect on job satisfaction and intention to leave at the individual level. Testing is carried out on employees who work in micro and small businesses to see the perceptions of employee suitability with business owners. Both dimensions are assessed separately not to assess multidimensional constructs of conformity as proposed by Jansen and Kristof-Brown (2006), but as other alternative forms of assessing conformity.

The results show that Person Owner Fit has a negative effect on Intention to come out but is not significant. So the suitability of the individual with the owner can reduce the employee's intention to come out even though it is not significant. In relation to employee job satisfaction the results show that the Person Owner Fit has a positive and significant influence, this condition is reflected in the length of time the employee works in the place where they currently work. The Person Job Fit dimension shows a positive and significant influence on employee job satisfaction and intention to leave, meaning that conformity with work leads to perceived job satisfaction by employees. The desire to be able to work in a larger company is also another factor that is considered by employees and triggers the desire to leave their place of work at this time.

By looking at these results, the aspect of conformity with the owner is an important factor in supporting multidimensional conformity. In the first year new employees seek information about new organizations to assess their suitability (Chatman, 1991), but then they will shift their focus to more dynamic aspects such as compatibility with work and the people around them. The ASA framework model suggests that someone can be attracted to a place, maybe they made a mistake so they found a discrepancy that caused them to leave" (Schneider, 1987), thus producing more homogeneity in those who remain (Schneider et al., 1995).

One interesting finding is that the suitability of individuals and owners has a significant effect on job satisfaction, in contrast to the results stated (J. A. Edwards \& Billsberry, 2010) in assessing conformity between individuals shows a standard regression weight that is very low and almost negligible in the equation, especially with the intention to leave and satisfaction. Other important factors can also determine perceptions of conformity, for example, people working alongside them, customers, staff, and other individuals they meet regularly (Kristof-Brown, Zimmerman, et al., 2005), so that the dimensions of employee suitability with owners need to be included in multidimensional fit.

\subsection{Implications}

Person Owner Fit and Person Job Fit can be recommended in supporting employee job satisfaction and reducing the intention or desire of employees to leave the company. The focus of suitability in the Person Owner Fit dimension places more emphasis on employee personality aspects with the owner's personality and the suitability of the employee's lifestyle with the owner's lifestyle, while conformity in the Person Job Fit dimension emphasizes the appropriateness of the employee's ability to the demands of the work and existing work.

\subsection{Research Limitations}

The main limitations of this study only use a cross-sectional design, so that further testing is needed in replicating the findings with longitudinal data. In assessing conformity, it is done by using self-reported steps or subjective judgments. This action is said to have more economic benefits than other types of data collection (Cable \& Judge, 1996, 1997; Kristof-Brown, 1996) but it is necessary to consider a more objective assessment. The sample used is only limited to MSMEs in Banyumas Indonesia with the business sector in the food processing and trading industry, so it needs to be developed in a wider scope so that more varied results can be obtained in assessing the suitability of individuals with their owners.

\section{CONCLUSION}

The Person Owner Fit dimension is a new dimension that adds multidimensional conformity in the Person Environment Fit theory, so the theory can be applied to organizations with various business scales. The development of the Person Owner Fit dimension is an important aspect because it can be used to assess the suitability that can affect employees in their intention to leave the workplace and influence their job satisfaction. 


\section{REFERENCES}

Adkins, C. L., Russell, C. J., Werbel, J. D. (1994). Judgments of fit in the selection process: The role of work value congruence. Personnel Psychology, 47(3), 605-623.

Aggarwal, U., Bhargava, S. (2010). Predictors and Outcomes of Relational and Transactional Psychological Contract. Psychological Studies, 55(3), 195-207. doi:10.1007/s12646-010-0033-2

Antonioni, D., Park, H. (2001). The effects of personality similarity on peer ratings of contextual work behaviors. Personnel Psychology, 54(2), 331-360.

Ashkanasy, N. M., O'connor, C. (1997). Value congruence in leader-member exchange. The Journal of Social Psychology, $137(5), 647-662$.

Badan Pusat Statistik, Kabupaten Banyumas. (2017). In.

Bauer, T. N., Green, S. G. (1996). Development of leader-member exchange: A longitudinal test. Academy of management Journal, 39(6), 15381567.

Belk, R. W. (1988). Possessions and the extended self. Journal of consumer research, 15(2), 139-168.

BI, U. (2011). Kelayakan Pendirian Lembaga Pemeringkat Kredit Bagi Usaha Mikro, Kecil, Dan Menengah Di Indonesia: Bank Indonesia.

Blau, P. M. (1964). Exchange and power in social life: Transaction Publishers.

Brayfield, A. H., Rothe, H. F. (1951). An index of job satisfaction. Journal of applied psychology, 35(5), 307.

Brief, A. P., Weiss, H. M. (2002). Organizational behavior: Affect in the workplace. Annual review of psychology, 53(1), $279-307$.

Cable, D. M., DeRue, D. S. (2002). The convergent and discriminant validity of subjective fit perceptions. Journal of applied psychology, 87(5), 875.

Cable, D. M., Judge, T. A. (1996). Person-organization fit, job choice decisions, and organizational entry. Organizational behavior and human decision processes, 67(3), 294-311.

Cable, D. M., Judge, T. A. (1997). Interviewers' perceptions of person-organization fit and organizational selection decisions. Journal of applied psychology, 82(4), 546.

Cammann, C., Fichman, M., Jenkins, D., Klesh, J. (1979). The Michigan organizational assessment questionnaire. Unpublished manuscript, University of Michigan, Ann Arbor.

Caplan, R. D. (1983). Person-environment fit: Past, present, and future. Stress research, 35(78), 173-187.

Cardon, M. S., Stevens, C. E. (2004). Managing human resources in small organizations: What do we know? Human resource management review, 14(3), 295-323.

Chatman, J. A. (1989). Improving interactional organizational research: A model of person-organization fit. Academy of management Review, 14(3), 333-349.

Chatman, J. A. (1991). Matching people and organizations: Selection and socialization in public accounting firms. Paper presented at the Academy of Management proceedings.

Chen, X.-P., Hui, C., Sego, D. J. (1998). The role of organizational citizenship behavior in turnover: Conceptualization and preliminary tests of key hypotheses. Journal of applied psychology, 83(6), 922.

Chuang, A., Judge, T. A., Liaw, Y. J. (2012). Transformational leadership and customer service: A moderated mediation model of negative affectivity and emotion regulation. European Journal of Work and Organizational Psychology, 21(1), 28-56.

Chuang, A., Shen, C. T., Judge, T. A. (2016). Development of a multidimensional instrument of person - environment fit: The Perceived Person Environment Fit Scale (PPEFS). Applied Psychology, 65(1), 66-98.

Colbert, A. E. (2004). Understanding the effects of transformational leadership: The mediating role of leader-follower value congruence.

Dabos, G. E., Rousseau, D. M. (2004). Mutuality and reciprocity in the psychological contracts of employees and employers. Journal of Applied Psychology, 89(1), 52.

Dimarco, N. (1975). Life style, work group structure, compatibility, and job satisfaction. Academy of Management journal, $18(2)$, 313-322.

Dittmar, H. (1992). The social psychology of material possessions: To have is to be: Harvester Wheatsheaf and St. Martin's Press.

Donaldson, L., Davis, J. H. (1991). Stewardship theory or agency theory: CEO governance and shareholder returns. Australian Journal of management, 16(1), 49-64.

Edwards, J. A., Billsberry, J. (2010). Testing a multidimensional theory of person-environment fit. Journal of Managerial Issues, $476-493$. 
Edwards, J. R. (1991). Person-job fit: A conceptual integration, literature review, and methodological critique: John Wiley \& Sons.

Edwards, J. R. (1996). An examination of competing versions of the person-environment fit approach to stress. Academy of management Journal, 39(2), 292-339.

Edwards, J. R. (2008). 4 person-environment fit in organizations: an assessment of theoretical progress. Academy of Management Annals, 2(1), 167-230.

Engle, E. M., Lord, R. G. (1997). Implicit theories, self-schemas, and leader-member exchange. Academy of management Journal, 40(4), 9881010.

Ferdinand, T. A. (2006). Metode Penelitian Manajemen: Pedoman Penulisan Skripsi. Tesis,dan Disertasi Ilmu Manajemen, (Vol. ed.1.). Semarang: BP-UNDIP.

Filotheos Ntalianis, L. D., Christian Vandenberghe. (2015). Owner-employee relations in small firms. Journal of Managerial Psychology, Vol. 30 Iss 7, 832 - 846. doi:10.1108/JMP-01-2013-0028

\subsection{8/JMP-03-2013-0088}

French, J. R. (1974). Adjustment as person-environment fit. Coping and adaptation.

French, J. R., Kahn, R. L. (1962). A programmatic approach to studying the industrial environment and mental health. Journal of social issues, 18(3), 1-47.

Gatewood, R. D., Feild, H. S. (1987). A personnel selection program for small business. journal of small business management, $25(4), 16$.

George;, J. M., Jones, G. R. (2012). Understanding and managing organizational behavior (6 ed.). New Jersey: Prentice Hall.

Graen, G., Cashman, J. F. (1975). A role-making model of leadership in formal organizations: A developmental approach. Leadership frontiers, $143,165$.

Graves, L. M., Powell, G. N. (1995). The Effect of sex similarity on recruiters'evaluations of actual applicants: a test of the similarity-attraction paradigm. Personnel Psychology, 48(1), 85-98.

Harrison, D. A. (2007). Pitching fits in applied psychological research: making fit methods I-'it theory. Perspectives on organizational fit, 389.

Hoffman, B. J., Bynum, B. H., Piccolo, R. F., Sutton, A. W. (2011). Person-organization value congruence: How transformational leaders influence work group effectiveness. Academy of Management Journal, 54(4), 779-796.

Holland, J. L. (1997). Making vocational choices: A theory of vocational personalities and work environments: Psychological Assessment Resources.

Hom, P. W., Griffeth, R. W. (1995). Employee Turnover (South-Western, Cincinnati, OH).

Homans, G. C. (1958). Social behavior as exchange. American journal of sociology, 63(6), 597-606.

House, R. J., Shane, S. A., Herold, D. M. (1996). Rumors of the death of dispositional research are vastly exaggerated. Academy of management review, 21(1), 203-224.

Ilies, R., Judge, T. A. (2002). Understanding the dynamic relationships among personality, mood, and job satisfaction: A field experience sampling study. Organizational Behavior and Human Decision Processes, 89(2), 1119-1139.

Jack, S., Hyman, J., Osborne, F. (2006). Small entrepreneurial ventures culture, change and the impact on HRM: A critical review. Human resource management review, 16(4), 456-466.

James, W. (1890). The Principles of Psychology (Vol. 2). New York, NY: Holt.

Jaramillo, F., J. P. Mulki., Solomon, P. (2006). The role of ethical climate on salesperson's role stress, job attitudes, turnover intention, and job performance. Journal of Personal Selling and Sales Management, 26(3), 271-282.

Judge, T. A., Larsen, R. J. (2001). Dispositional affect and job satisfaction: A review and theoretical extension. Organizational Behavior and Human Decision Processes, 86(1), 67-98.

Krishnan, V. R. (2002). Transformational leadership and value system congruence. International Journal of Value-Based Management, 15(1), 1933.

Kristof-Brown, A. L. (1996). Person-organization fit: An integrative review of its conceptualizations, measurement, and implications. Personnel Psychology, 49(1), 1-49.

Kristof-Brown, A. L., Guay, R. P. (2011). Person-Environment Fit. 
Kristof-Brown, A. L., Stevens, C. K. (2001). Goal congruence in project teams: Does the fit between members' personal mastery and performance goals matter? Journal of applied psychology, 86(6), 1083-1095.

Kristof-Brown, A. L. (2000). Perceived Applicant Fit: Distinguishing Between Recruiters' perceptions Of Person-Job And Person-Organization Fit. Personnel Psychology, 53(3), 643-671.

Kristof-Brown, A. L., Barrick, M. R., Kay Stevens, C. (2005). When opposites attract: a multi-sample demonstration of complementary personteam fit on extraversion. Journal of Personality, 73(4), 935-958.

Kristof-Brown, A. L., Zimmerman, R. D., Johnson, E. C. (2005). Consequences of individuals'fit at work: a meta analysis of person job, person organization, person group, and person supervisor fit. Personnel Psychology, 58(2), 281-342.

Kroeger, N. W. (1995). Person-Environment Fit in the Final Jobs of Retirees. The Journal of Social Psychology, 135(5), 545-551. doi:10.1080/00224545.1995.9712227

Lauver, K. J., Kristof-Brown, A. (2001). Distinguishing between employees' perceptions of person-job and person-organization fit. Journal of Vocational Behavior, 59(3), 454-470.

Li, C.-K., Hung, C.-H. (2010). An examination of the mediating role of person-job fit in relations between information literacy and work outcomes. Journal of Workplace Learning, 22(5), 306-318.

Liden, R. C., Wayne, S. J., Stilwell, D. (1993). A longitudinal study on the early development of leader-member exchanges. Journal of applied psychology, 78(4), 662.

Lincoln, J. R., Miller, J. (1979). Work and friendship ties in organizations: A comparative analysis of relation networks. Administrative Science Quarterly, 181-199.

Locke, E. A. (1976). The nature and causes of job satisfaction. Handbook of industrial and organizational psychology.

Matlay, H. (1999). Employee relations in small firms: A micro-business perspective. Employee relations, 21(3), 285-295.

Meglino, B. M., Ravlin, E. C., Adkins, C. L. (1991). Value congruence and satisfaction with a leader: An examination of the role of interaction. Human Relations, 44(5), 481-495.

Miles, R. E. (1964). Attitudes toward management theory as a factor in managers' relationships with their superiors. Academy of management Journal, 7(4), 308-314.

Millward, L. J., Brewerton, P. M. (1999). Contractors and their psychological contracts. British Journal of management, 10(3), $253-274$.

Montes, S. D., Irving, P. G. (2008). Disentangling the effects of promised and delivered inducements: relational and transactional contract elements and the mediating role of trust. Journal of Applied Psychology, 93(6), 1367.

Moos, R. H. (1987). Person-environment congruence in work, school, and health care settings. Journal of Vocational Behavior, 31(3), 231-247.

Muchinsky, P. M., Monahan, C. J. (1987). What is person-environment congruence? Supplementary versus complementary models of fit. Journal of Vocational Behavior, 31(3), 268-277.

O'Reilly, C. A., Caldwell, D. F., Barnett, W. P. (1989). Work group demography, social integration, and turnover. Administrative Science Quarterly, 21-37.

Parsons, F. (1909). Choosing a vocation: Houghton Mifflin.

Phillips, A. S., Bedeian, A. G. (1994). Leader-follower exchange quality: The role of personal and interpersonal attributes. Academy of management Journal, 37(4), 990-1001.

Piasentin, K. A., Chapman, D. S. (2007). Perceived similarity and complementarity as predictors of subjective person-organization fit. Journal of Occupational and Organizational Psychology, 80(2), 341-354.

Randolph, D. S., Johnson, S. P. (2005). Predicting the effect of extrinsic and intrinsic job satisfaction factors on recruitment and retention of rehabilitation professionals. Journal of Healthcare management, 50(1), 49.

Rynes, S. L., Gerhart, B. (1993). Recruiter perceptions of applicant fit: Implications for individual career preparation and job search behavior. Journal of Vocational Behavior, 43(3), 310-327.

Saari, L. M., Judge, T. A. (2004). Employee attitudes and job satisfaction. Human Resource Management: Published in Cooperation with the School of Business Administration, The University of Michigan and in alliance with the Society of Human Resources Management, 43(4), 395407.

Sabanciogullari, S., Dogan, S. (2015). Relationship between job satisfaction, professional identity and intention to leave the profession among nurses in Turkey. J Journal of nursing management, 23(8), 1076-1085.

Sartika, T., Soedjoedono, A. R. (2002). Ekonomi Skala Kecil/Menengah dan Koperasi. Ghalia Indonesia. Jakarta. 
Schaubroeck, J., Lam, S. S. (2002). How similarity to peers and supervisor influences organizational advancement in different cultures. Academy of management Journal, 45(6), 1120-1136.

Schneider, B. (1987). The people make the place. Personnel Psychology, 40(3), 437-453.

Schneider, B., Goldstiein, H. W., \& Smith, D. B. (1995). The ASA framework: An update. Personnel Psychology, 48(4), 747-773.

Spanjol, J., Tam, L., Tam, V. (2015). Employer-employee congruence in environmental values: An exploration of effects on job satisfaction and creativity. J Journal of Business Ethics, 130(1), 117-130.

Steiner, D. D., Dobbins, G. (1989). The role of work values in leaders' attributions and the development of leader-member exchanges. International Journal of Management, 6(1), 81-90.

Super, D. E. (1953). A theory of vocational development. American psychologist, 8(5), 185.

Tsui, A. S., O'reilly, C. A. (1989). Beyond simple demographic effects: The importance of relational demography in superior-subordinate dyads. Academy of management Journal, 32(2), 402-423.

Turban, D. B., Dougherty, T. W. (1994). Role of protégé personality in receipt of mentoring and career success. Academy of management Journal, 37(3), 688-702.

Turban, D. B., Jones, A. P. (1988). Supervisor-subordinate similarity: types, effects, and mechanisms. Journal of applied psychology, $73(2), 228$.

Valentine, S., Godkin, L., Fleischman, G. M., Kidwell, R. (2011). Corporate ethical values, group creativity, job satisfaction and turnover intention: The impact of work context on work response. Journal of business ethics, 98(3), 353-372.

Vianen, A. E. (2000). Person-organization fit: The match between newcomers'and recruiters'preferences for organizational cultures. Personnel Psychology, 53(1), 113-149.

Walker, E., Brown, A. (2004). What success factors are important to small business owners? International small business journal, 22(6), 577-594.

Wang, M., Zhan, Y., McCune, E., Truxillo, D. (2011). Understanding newcomers'adaptability and work-related outcomes: Testing the mediating roles of perceived P-E fit variables. Personnel psychology, 64(1), 163-189.

Werbel, J. D., Gilliland, S. W. (1999). Person-environment fit in the selection process.

Williamson, O. E. (1981). The economics of organization: The transaction cost approach. American journal of sociology, 87(3), 548-577.

Witt, L. (1998). Enhancing organizational goal congruence: A solution to organizational politics. Journal of applied psychology, 83(4), 666.

Yu, K. Y. T. (2016). Inter-Relationships among different types of Person-Environment fit and job satisfaction. J Applied Psychology, 65(1), 38-65. 